\title{
Hipermetilasi Promoter Gen Apoptotic Protease-Activating Factor-1 [APAF1] pada Leukemia Limfoblastik Akut Anak
}

\author{
Ika Fidianingsih, ${ }^{*}$ Eddy Supriyadi, ${ }^{* *}$ Dewajani Purnomosari ${ }^{* * *}$ \\ *Departemen Histologi, Fakultas Kedokteran, Universitas Islam Indonesia, Yogyakarta \\ "Departemen Ilmu Kesehatan Anak, RSUP Dr Sardjito, Yogyakarta \\ *** Departemen Histologi dan Biologi Sel, Fakultas Kedokteran Universitas Gadjah Mada, Yogyakarta
}

\begin{abstract}
Latar belakang. Hipermetilasi DNA ditengarai berperan penting dalam inaktivasi gen tumor supresor (tumor suppressor gene $=$ TSG) pada keganasan hematologi. Gen APAF1 mempunyai frekuensi hipermetilasi cukup tinggi pada leukemia limfoblastik akut (LLA) anak. Inaktivasi gen APAF1 menyebabkan sel progenitor limfoid mengalami gangguan apoptosis.

Tujuan. Mengetahui frekuensi hipermetilasi promoter APAF1 pada pasien yang terdiagnosis LLA anak di RSUP DR. Sardjito Yogyakarta, serta hubungannya dengan karakteristik umur, jumlah leukosit dan imunofenotip.

Metode. Dari 32 DNA sampel mononuklaer darah perifer pasien LLA anak saat terdiagnosis (Oktober 2004-Mei 2009) dideteksi menggunakan methylation spesific polymerase chain reaction (MSP). Analisis statistik dilakukan dengan menggunakan uji Fisher exact.

Hasil. Hipermetilasi APAF1 terjadi pada $26(81,3 \%)$ pasien LLA anak. Hipermetilasi APAF1 lebih banyak terjadi pada kelompok umur 1-10 tahun, jumlah leukosit $\geq 50000 / \mu 1$, dan imunofenotip $B$, dibanding kelompok umur $<1$ tahun dan $>10$ tahun, jumlah leukosit $<50000 / \mu l$, dan imunofenotip T, walaupun demikian perbedaannya tidak bermakna $(\mathrm{p}>0,05)$.

Kesimpulan. Frekuensi hipermetilasi APAF1 mempunyai frekuensi cukup tinggi pada pasien LLA anak dan tidak berhubungan dengan umur, jumlah leukosit dan imunofenotip. Sari Pediatri 2012;14(2):79-83.
\end{abstract}

Kata kunci: hipermetilasi, APAF1, leukemia limfoblastik akut

\footnotetext{
Alamat korespondensi:

Dr. Ika Fidianingsih, Fakultas Kedokteran UII, Jl. Kaliurang Km 14,5 Yogyakarta. Telp. (0274) 7815120, E-mail: ikafidianingsih@ymail.com. Dr. Eddy Supriyadi, Sp.A, Bagian Ilmu Kesehatan Anak, RSUP Dr. Sardjito, Jl Kesehatan No.1 Sekip Utara Yogyakarta. Telp. (0274) 553142, E-mail: e.supriyadi@yahoo.co.id
}

eukemia limfoblasik akut (LLA) adalah kanker
yang paling sering terjadi pada anak. Kasus
baru LLA per tahun terjadi sebanyak kurang
lebih 3000 di Amerika, 5000 di Eropa $^{1}$ dan
diperkirakan 2000-3000 kasus di Indonesia. ${ }^{2}$ Jumlah
kejadian LLA juga cenderung meningkat tiap tahun. 
Dalam kurun waktu 10 tahun (dari tahun 1999 sampai tahun 2009) terjadi peningkatan angka kejadian LLA anak sebesar hampir 3 kali lipat di RSUP DR. Sardjito. $^{3}$

Peningkatan kejadian LLA diimbangi oleh keberhasilan terapi LLA. Overall survival 5 tahun pasien LLA anak yang terdiagnosis 2000-2005 sebesar 96\% di Amerika ${ }^{4}$ dan overall survival 6 tahun yang terdiagnosis 1999-2002 di RSUP DR.Sardjito sebesar 71\%.5 Keberhasilan terapi LLA didukung oleh semakin berkembangnya penelitian mengenai mekanisme molekuler tumorigenesis LLA seperti aneuploidi, translokasi kromosom, dan mutasi, ${ }^{6}$ namun perkembangan terbaru menengarai peranan metilasi DNA dalam mekanisme molekuler LLA. ${ }^{7}$

Metilasi DNA adalah penambahan gugus metil pada basa sitosin yang mendahului basa guanin $(\mathrm{CpG})$ pada urutan 5'-3' tanpa disertai perubahan susunan urutan basa. Daerah promoter yang mengalami metilasi akan mengikat protein Methyl $C_{p} G$ Binding Domain (MBD), sehingga mencegah ikatan dengan faktor transkripsi dan menyebabkan tidak terekspresinya suatu gen. ${ }^{8}$ Apabila metilasi terjadi pada promoter tumor suppressor gene (TSG), maka akan mengakibatkan terganggunya proses selular seperti kontrol proliferasi, diferensiasi dan apoptosis, yang memicu terjadinya kanker. ${ }^{9}$ Hipermetilasi TSG berhubungan dengan progresivitas kanker dan diduga memiliki potensi penggunaan klinis sebagai biomarker kanker yaitu untuk deteksi dini, diagnosis, prognosis maupun prediktor respon terapi. ${ }^{7}$ Pasien LLA yang mengalami hipermetilasi pada beberapa gen mempunyai prognosis lebih buruk dibanding pasien LLA dengan hipermetilasi pada sedikit gen atau tidak mengalami hipermetilasi sama sekali. ${ }^{10-12}$

Gen apoptotic protease-activating factor1 (APAF1) merupakan suatu TSG. Penurunan ekspresi APAF1 berhubungan dengan kejadian banyak kanker dan kegagalan kemoterapi. ${ }^{13}$ Penurunan ekspresi APAF1 pada leukemia telah dibuktikan, dan tidak berhubungan dengan mutasi maupun translokasi kromosom tetapi berhubungan dengan hipermetilasi. ${ }^{14}$ Hipermetilasi promoter APAF 1 menunjukkan frekuensi cukup tinggi (35\%) pada pasien LLA anak di Spanyol, ${ }^{10}$ tetapi tidak mengalami metilasi pada LLA di Hongkong. ${ }^{15}$ Sel leukemia dengan metilasi APAF1 mengalami apoptosis setelah diberi agen penghambat metilasi APAF1. ${ }^{16,17}$
Karakteristik klinis, biologis, dan molekuler telah digunakan untuk menentukan stratifikasi dan menunjukkan hubungan yang erat dengan prognosis atau keluaran klinis. ${ }^{4}$ Di Indonesia, stratifikasi LLA hanya ditentukan oleh karakteristik klinis dan biologis saja, antara lain umur, jumlah leukosit, dan imunofenotip. ${ }^{18}$ Molekuler belum dipakai untuk menentukan stratifikasi. Studi tentang hubungan hipermetilasi promoter gen APAF1 pada LLA anak dengan umur, jumlah leukosit, dan imunofenotip belum banyak dilakukan, masih menunjukkan hasil yang bervariasi pada beberapa ras dan belum dilakukan di Indonesia. Penelitian kami bertujuan untuk mengetahui frekuensi hipermetilasi promoter gen APAF1 pada pasien LLA anak di RSUP DR. Sardjito serta hubungannya dengan umur, jumlah leukosit, dan imunofenotip.

\section{Metode}

Desain penelitian cross sectional, sampel berupa mononuklear darah perifer dari 32 pasien LLA anak RSUP DR Sardjito, Yogyakarta tahun 2004 - 2009. Sampel pasien LLA dipilih yang mempunyai data lengkap, mempunyai morfologi L1 dan L2, serta mempunyai limfoblas sumsum tulang dan perifer lebih dari 25\%. Kriteria eksklusi apabila kualitas DNA rendah. Data umur, jumlah leukosit, dan imunofenotip diperoleh dari rekam medis.

Isolasi DNA (Qiagen) dan modifikasi bisulfit (Qiagen) dilakukan dengan prosedur sesuai protokol kit. Modifikasi bisulfit dilakukan untuk mengubah seluruh basa sitosin menjadi basa urasil, kecuali basa sitosin yang termetilasi. ${ }^{10}$ Masing-masing sampel dilakukan PCR dengan menggunakan primer metilasi ${ }^{16}$ Kondisi polymerase chain reaction (PCR) adalah $96^{\circ} \mathrm{C}$ selama 4 menit, kemudian 40 siklus untuk $94^{\circ} \mathrm{C}$ (50 detik); $58^{\circ} \mathrm{C}$ APAF1 (1 menit); $72^{\circ} \mathrm{C}$ (1 menit). Kontrol positif metilasi yaitu DNA yang sudah dibuat menjadi termetilasi pada semua $\mathrm{CpG}$ dengan menggunakan SssI methyltransferase (Biolabs). Hasil PCR dilakukan elektroforesis menggunakan agarose gel $2 \%$ dan dibaca dengan sinar ultraviolet tanpa mengetahui status karakteristik pasien LLA.

Analisis statistik hubungan hipermetilasi dengan karakteristik umur, jumlah leukosit dan imunifenotip digunakan uji kai kuadrat jika memenuhi syarat dan alternatifnya adalah uji Fisher exact. Analisis statistik dilakukan menggunakan program SPSS 17.0. 


\section{Hasil}

Persentase jumlah pasien LLA anak perempuan dan lelaki sama. Delapan puluh tujuh persen sampel adalah kelompok anak berusia 1-10 tahun, dengan rerata usia 4 tahun, dan median umur 3-4 tahun. Sebagian besar sampel mempunyai imunofenotip tipe $\mathrm{B}$, mempunyai jumlah leukosit $\geq 50000 / \mu l$, dan berstratifikasi risiko

Tabel 1. Karakteristik pasien LLA anak

\begin{tabular}{lc}
\hline Karakteristik & $\begin{array}{c}\text { Jumlah } \\
(\mathrm{n}=32)\end{array}$ \\
\hline Jenis kelamin & \\
$\quad$ Perempuan & 16 \\
Lelaki & 16 \\
Umur (tahun) & \\
$1-10$ & 28 \\
$\quad<1$ dan $>10$ & 4 \\
Jumlah leukosit $(\mu \mathrm{l})$ & \\
$\quad<50000$ & 12 \\
$\quad$ 250000 & 20 \\
Imunofenotip & \\
$\quad$ Tipe B & 28 \\
Tipe T & 4 \\
Stratifikasi & \\
$\quad$ Risiko standar & 6 \\
Risiko tinggi & 26 \\
Hipermetilasi APAF1 & \\
$\quad$ Ada & 26 \\
Tidak & 6 \\
\hline
\end{tabular}

tinggi. Pasien LLA anak mengalami hipermetilasi promoter APAF1 sebesar 81,3\% (Tabel 1).

Pasien LLA anak yang mengalami hipermetilasi APAF1 lebih banyak terjadi pada kelompok umur 1-10 tahun, jumlah leukosit $\geq 50000 / \mu$ dan imunofenotip $\mathrm{B}$, dibanding umur $<1$ dan $>10$ tahun, jumlah leukosit $<50000 / \mu l$ serta imunofenotip T, tetapi tidak berbeda bermakna (Tabel 2). Hasil MSP setelah dielektroforesis dengan agarose gel tertera pada Gambar 1.

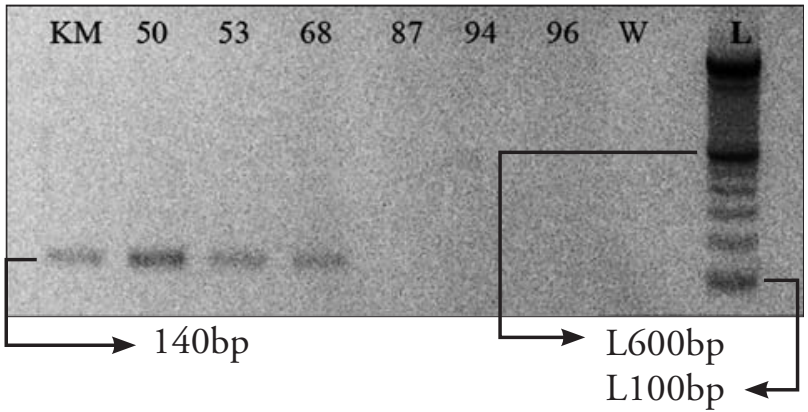

Gambar 1. Hasil MSP APAF1. KM : kontrol positif metilasi; Nomer 50, 53, 68: sampel mengalami hipermetilasi; Nomer 87, 94, 96: sampel tidak mengalami hipermetilasi; W: blank (air); L: Ladder marker DNA 100bp.

\section{Pembahasan}

Hipermetilasi APAF1 pada penelitian kami, relatif lebih tinggi dari pada penelitian sebelumnya yang bervariasi antara 0\%-35\%. ${ }^{10,15}$ Beberapa hal yang menyebabkan perbedaan antara lain ras, karakteristik klinis, jumlah

Tabel 2. Karakteristik pasien LLA anak berdasar ada tidaknya hipermetilasi APAF1

\begin{tabular}{lccc}
\hline Gen & $\begin{array}{c}\text { Hipermetilasi } \\
\mathrm{n}\end{array}$ & $\begin{array}{c}\text { Tidak hipermetilasi } \\
\mathrm{n}\end{array}$ & $\mathrm{p}$ \\
\hline Umur (tahun) & & & 0,58 \\
$\quad 1-10$ & 23 & 5 & \\
$\quad<1$ dan $>10$ & 3 & 1 & 0,6 \\
Jumlah leukosit $(\mu \mathrm{l})$ & & 7 & \\
$\quad<50000$ & 10 & 6 & 0,15 \\
$\quad 250000$ & 16 & & \\
Imunofenotip & & 4 & 0,69 \\
$\quad$ Tipe B & 24 & 2 & \\
$\quad$ Tipe T & 2 & & \\
Stratifikasi & & 1 & \\
$\quad$ Risiko standar & 5 & 5 & \\
$\quad$ Risiko tinggi & 21 & &
\end{tabular}

p : uji statistik Fisher exact (signifikan jika p<0,05) 
sampel yang digunakan, dan jenis primer yang berbeda. Paparan kronis lingkungan, diet, dan penyakit lain turut mempengaruhi kejadian hipermetilasi. ${ }^{19}$ Karakteristik pasien LLA pada penelitian Roman-Gomez $d k k^{10}$ berbeda dengan penelitian kami. Sebagian besar sampel pada penelitian kami mempunyai jumlah leukosit $\geq 50000 / \mu l$, sebaliknya pada penelitian Roman-Gomez $\mathrm{dkk}^{10}$ mempunyai jumlah leukosit $<50000 / \mu \mathrm{l}$. Primer yang berbeda menunjukkan lokasi CpG berbeda dan memungkinkan perbedaan status metilasi. ${ }^{20}$

Uji Fishers exact tidak menjumpai hubungan antara hipermetilasi promoter gen APAF1 dengan umur. Hal tersebut sesuai dengan penelitian sebelumnya. ${ }^{10}$ Roman-Gomez dkk ${ }^{10}$ menyebutkan bahwa banyaknya gen yang mengalami hipermetilasi berhubungan dengan prognosis buruk, sementara LLA kelompok umur $<1 />10$ tahun mempunyai prognosis buruk. ${ }^{6}$ Namun kami menemukan bahwa pada kelompok umur $<1 />10$ tahun mengalami hipermetilasi lebih sedikit dibanding kelompok umur 1-10 tahun. Hal tersebut menunjukkan bahwa tidak hanya hipermetilasi yang mempengaruhi mekanisme terjadinya LLA. Selama ini kelompok umur $<1$ tahun dihubungkan dengan prognosis buruk karena terdapat MLL gene rearrangement, sedangkan anak umur $>10$ tahun karena terdapat kromosom philadelphia atau translokasi BCRABL. ${ }^{4}$ Hubungan umur dengan hipermetilasi pada pasien LLA, selama ini ditunjukkan dengan banyaknya TSG yang mengalami metilasi berhubungan dengan usia dewasa, ${ }^{11,12}$ sementara penelitian kami hanya mengambil sampel pasien LLA anak.

Hubungan antara hipermetilasi promoter APAF1 dengan jumlah leukosit tidak ditemukan pada penelitian kami. Hal tersebut sesuai dengan penelitian sebelumnya. ${ }^{10}$ Pasien LLA anak dengan jumlah leukosit $\geq 50000 / \mu$ l mengalami hipermetilasi lebih tinggi dibanding LLA dengan jumlah leukosit $<50000 / \mu l$, karena hipermetilasi promoter APAF1 menyebabkan APAF1 tidak terekspresi, ${ }^{16,17}$ sehingga Procacspase 9 tidak dapat diaktifkan, selanjutnya caspase 3 juga tidak aktif, akibatnya sel limfoid tidak mengalami apoptosis. Hal tersebut menyebabkan akumulasi leukosit. ${ }^{9}$

Apoptosis selain berperan dalam keseimbangan jumlah sel, juga berperan dalam pencegahan terjadinya transformasi sel kanker. Apabila suatu kerusakan DNA tidak dapat diperbaiki, maka sel cenderung apoptosis untuk mencegah mutasi. ${ }^{9}$ Selama ini, gen p53 yang paling dikenal berperan dalam apoptosis dan perbaikan DNA, namun ekspresi p53 memerlukan ekspresi APAF1 untuk terjadinya apoptosis. ${ }^{9}$ Ekspresi APAF1 yang menurun berhubungan dengan kegagalan apoptosis. ${ }^{13}$ Tingginya frekuensi hipermetilasi APAF1 memungkinkan transformasi sel limfoid progenitor.

Apoptosis merupakan salah satu mekanisme target pengobatan kanker. Kegagalan terapi dihubungkan dengan kegagalan sel kanker dalam apoptosis. ${ }^{9}$ Frekuensi hipermetilasi APAF1 yang tinggi pada penelitian ini memungkinkan dugaan bahwa respon terapi pasien buruk. Penelitian sebelumnya menunjukkan terdapat hubungan antara hipermetilasi APAF1 pada melanoma maligna dan tumor kandung kencing dengan prognosis yang buruk. ${ }^{13}$ Penelitian lebih lanjut mengenai hubungan hipermetilasi APAF1 pada pasien LLA anak ini dengan respon pengobatan perlu dilakukan. Apabila benar, maka hipermetilasi APAF1 dapat digunakan sebagai prediktor respon terapi dan pertimbangan dalam menentukan terapi pasien LLA.

Hipermetilasi promoter APAF1 tidak berhubungan dengan imunofenotip dan stratifikasi, hal tersebut sesuai dengan penelitian sebelumnya. ${ }^{10}$ Peranan APAF1 dalam proses diferensiasi limfosit juga belum dibuktikan, meskipun Lindholm dan Arumae ${ }^{21}$ menyebutkan adanya peran APAF1 dalam proses diferensiasi sel saraf tikus. Penelitian lebih lanjut mengenai peran APAF1 dalam proses perkembangan limfosit perlu dilakukan.

Disimpulkan bahwa hipermetilasi promoter gen APAF1 mempunyai frekuensi cukup tinggi pada pasien LLA anak, tetapi tidak terdapat hubungan dengan umur, jumlah leukosit, dan imunofenotip. Diperlukan penelitian lebih lanjut mengenai hubungan hipermetilasi APAF1 dengan respon terapi pada sampel yang lebih besar.

\section{Ucapan terimakasih}

Ucapan terimakasih disampaikan kepada 1) Proyek Risbin Iptekdok yang telah mendanai penelitian, 2) Kepala Laboratorium Biologi Molekuler FK UGM yang telah mengizinkan penggunaan fasilitas laboratorium untuk penelitian ini, dan 3) Bapak Ignatius Purwanto yang telah membantu data rekam medis pasien LLA anak.

\section{Daftar pustaka}

1. Margolin JF, Steuber CP, Poplacl DG. Acute lymphoblastic leukemia. Dalam: Pizzo PA, Poplack DG, penyunting. 
Principles and practice of pediatric oncology. Fourth edition. Philadelphia: Lippinkot William\&Wilkins; 2002.h.489-544.

2. Sutaryo, Sumadiono, Suhadi. The pilot protocol of wijaya kusuma acute lymphoblastic leukemia of childhood 1999.

Yogyakarta: Indonesian Multicentre Study, Gadjah Mada University Press; 1999.

3. Rekam medis Bagian Hematologi dan Onkologi RSUP DR. Sardjito; 2010.

4. Pui $\mathrm{CH}$, Evans WE. Treatment of acute lymphoblastic leukemia. N Engl J Med 2006;354:166-78.

5. Mulatsih S, Sumadiono, Sutaryo, Purwanto. The result of treating children's acute lymphoblastic leukemia (ALL) in DR. Sardjito Hospital With WK-ALL protocol, 1992-2002. Buletin Ilmu Kesehatan Anak FK Airlangga/RSUD Dr.Soetomo Surabaya. Januari 2005.

6. Pui CH, Relling MV, Downing JR. Mechanisms of disease acute lymphoblastic leukemia. N Engl J Med 2004; 350:1535-48.

7. Esteller M. Epigenetics in cancer. N Engl J Med 2008;358:1148-59.

8. Das PM, Singal R. DNA methylation and cancer. J Clin Oncol 2004;22: 4632-40.

9. Weinberg RA. The biology of cancer. New York: Garland Science; 2007. h.209-356.

10. Roman Gomez J, Jimenez Velasco A, Castillejo JA, Torres A. Promoter hypermethylation of cancer-related genes: a strong independent prognostic factor in acute lymphoblastic leukemia. Blood 2004;104:2492-8.

11. Gutierrez MI, Siraj AK, Bhargava M, Bhatia K. Concurrent methylation of multiple genes in chilhood ALL:Correlation with phenotype and molecular subgroup. Leukemia 2003;17:1845-50.

12. Canalli AA, Yang H, Jeha S, Hoshino K, Garcia-Manero
G. Aberrant DNA methylatian of a cell cycle regulatory pathway composed of p73, p15, and p57KIP2, is a rare event in children with acute lymphocytic leukemia. Leukemia Res 2005;29:881-5.

13. Christoph F, Weikert S, Kempkensteffen C, Schrader M. Regularly methylated novel pro-apoptotic genes associated with recurrence in trantitional cell cercinoma o bladder. Int J Cancer 2006; 119:1396-402.

14. Roman-Gomez J, Jimenez-Velasco A, Barrios M, Agirre $\mathrm{X}$. Poor prognosis in acute lymphoblastic leukemia may relate to promoter hypermethylation of cancer-related genes. Leuk Lymphoma 2007;48:1269-82.

15. Chim JCS, Chan WWL, Kwong YL. Epigenetic dysregulation of the DAP kinase/p14/HDM2/p53/Apaf-1 apoptosis pathway in acute leukaemias. J Clin Pathol 2008;61:844-7.

16. Fu WN, Bertoni F, Kelsey SM, Jia L. Role of DNA methylation in the suppression of Apaf-1 protein in human leukaemia. Oncogene 2003;22:451-5.

17. Furukawa Y, Sutheesophon K, Wada T, Furukawa Y. Methylation silencing of the Apaf-1 gene in acute leukemia. Mol Cancer Res 2005;3:325-34.

18. Ikatan Dokter Anak Indonesia (IDAI). Indonesian Protocol ALL 2006.

19. Christensen BC, Houseman EA, Marsit CJ, Kelsey KT. Aging and environmental exposures alter tissue-specific DNA methylation dependent upon CpG island contexs. PLoS Genet 2009;5:1-13.

20. Dobrovic A. Methods for Analysis of DNA Methylation. Dalam: Coleman WB, Tsongalis GJ, penyunting. Molecular diagnostics for the clinical laboratorian. New York: Humana Press Totowa; 2005.h.151-5.

21. Lindholm D, Arumäe U. Cell differentiation: reciprocal regulation of Apaf- 1 and the inhibitor of apoptosis proteins. J Cell Biol 2004;167:193-5. 